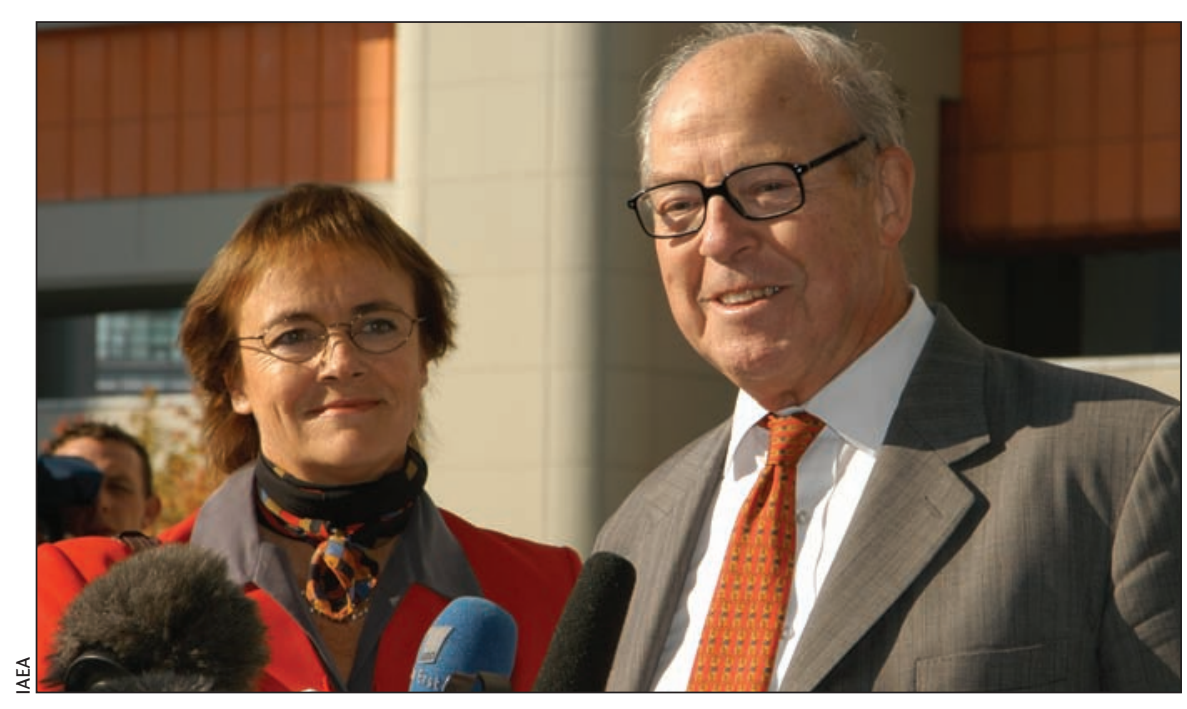

Hans Blix, head of the Weapons of Mass Destruction Commission, concludes that efforts to disarm have "stagnated."

to refrain from developing nuclear weapons and from testing. "If all great powers made sincere efforts to move the world toward nuclear disarmament, it might be less difficult to persuade other states to do likewise," Prof. Hans Blix told the Boston Globe.

The International Atomic Energy Agency (IAEA) also lamented the testing and breaking "de facto" of the global moratorium on nuclear explosive testing. Further "the addition of a new State with nuclear weapon capacity is a clear setback to international commitments to move towards nuclear disarmament."

At an Ottawa lecture 2 weeks before the test, Blix highlighted the results of a 2-year study by the Sweden-based WMDC. Its June 2006 report, Weapons of Terror: Freeing the World of Nuclear, Biological and Chemical Arms, concludes that global efforts to achieve arms limitation and disarmament have "stagnated" and makes 6o recommendations toward global cooperation on disarmament (www.wmdcommission.org).

The UN Secretary-General has urged the international community to consider the report's recommendations.

Blix, the former director general of the Vienna-based IAEA (I98I-97) and former executive chair of the UN Monitoring, Verification, and Inspection Commission (2000-03), warned, "We are at a crossroads." If we take the wrong turn, we are heading toward a new nuclear arms race.
Blix discussed current issues affecting the nuclear arms race, from an increase in world military expenditure to a policy shift that now accepts a first strike nuclear option. The US, he argued, believes it has the freedom to use pre-emptive nuclear action to counter a threat to its national security - and that threat no longer has to be imminent.

Blix's main message was that all governments currently possessing nuclear weapons must reduce their arsenals and stop producing plutonium and highly enriched uranium for nuclear weapons. "It is high time the nuclear weapons states move on with their commitment" to the Nuclear Non-Proliferation Treaty.

In addition, all nuclear-armed states must go forward with the Comprehensive Nuclear Test Ban Treaty, including ratification by those who haven't yet done so, such as the US and China. Third, verification of fissile material (by IAEA inspectors) must continue, and non-treaty countries such as India must agree to these safeguards.

Blix and the WMDC are unanimous in calling for a prohibition of nuclear weapons.

Given the lack of political will to change the state of nuclear affairs, Dr. Ron McCoy, immediate past co-president of IPPNW, wondered if it's time to shift focus from decision-makers to public opinion. Blix gave an emphatic yes. He questioned why US taxpayers accept military expenditure of up to I trillion dollars.
McCoy also pointed out that the fight against global warming could increase the threat of nuclear instability as more countries procure nuclear power stations. IPPNW recently published its 5 goals toward global abolition of nuclear weapons (www.ippnw.org).

Blix praised diplomacy as the way forward: "we need to create situations in which states do not feel the need for WMD." - Debra Martens, Ottawa

DOI:I0.1503/cmaj.061350

\section{News @ a glance}

Heart Strategy: Health minister Tony Clement says the federal government will shell out $\$ 8.4$ million $/ 2$ years to develop a comprehensive pan-Canadian heart health strategy. To be crafted by a 30 member committee led by cardiologist Eldon Smith, it will "provide a unifying framework for interventions along the whole continuum of care from prevention through treatment to rehabilitation and reintegration to the community," Clement told the Canadian Cardiovascular Congress. Once developed, it's envisioned the new strategy will parallel an existing \$260 million/5 year plan for cancer control.

Law suit: Describing themselves as "victims of an abuse of power," the 80oo-strong Quebec Federation of Medical Specialists have filed a suit in Quebec Superior Court against the province for passing legislation imposing a pay settlement that leaves them the lowest earning specialists in the country ( $\$ 233$ ooo/year as opposed to an average \$343000 nationally). Bill 37, passed last June, reduced the government's original contract offer and docked $\$ 50$ million from the settlements as a penalty. The specialists want it declared void, arguing that their civil rights have been breached by a provision which bans them from altering the practice in concert with one another, thereby preventing them from using work slowdowns as a bargaining tactic. - compiled by Wayne Kondro, CMAJ

DOI:Io.I503/cmaj.06I428 